\title{
The Estimation of Lake Naivasha Area Changes Using of Hydro-Geospatial Technologies
}

\author{
A. Ruhakana \\ Soil and Water Management Research Program \\ Rwanda Agriculture Board, Huye, Rwanda \\ aruhakana2012@gmail.com
}

\begin{abstract}
Remote Sensing (RS) and Geographical Information System (GIS) were proved as new technology to intervene in monitoring, managing and protecting environmental resources among others lake and water reservoir are mostly anxious resources. The objective of the study was to estimate the surface area change of the lake Naivasha using RS, GIS techniques and hydrological modeling for the lake water balance. Landat images Thematic Mapper/Enhanced Thematic Mapper Plus (TM/ETM+) taken respectively in the same month of January 1986; 1995; 2003 and 2010 were the input data used to assess the different changes of the lake area on one hand. on other hand the spread sheet data set helped to build the hydrological model to estimate the long term lake Level fluctuation, the rainfall versus evaporation as in flow and out flow from the lake. The lake volume showed the dynamic of ground water to simulate the long-term fluctuation of the lake level. The lake area changes from the model were calculated from the spread sheet input data from 1986 to 2003 while the lake area changes from the Landsat images were calculated from 1986 to 2010. The comparative results from the area lake changes both from Landsat images and hydrological model confirmed the correlation results, $45.72 \mathrm{Km}^{2}$ or $32.03 \%$ in 2010 for the Landsat while the hydrological model estimated to $12 \mathrm{~km}^{2}$ or $8 \%$ area reduction in 2003 .
\end{abstract}

Keywords: Area lake change, Geographical Information System, Hydrological model, Landsat images, Lake Naivasha, Remote Sensing 


\section{INTRODUCTION}

The lakes act as the essential components of the hydrological cycle and local ecosystems. Lake area changes are highly sensitive to both climate change and human activities (Ding et al.2006), There is a great significance in mapping lakes and estimating their area changes accurately because it contributes not only in understanding the relevance of lake variations but also in utilizing and protecting of lake water resources ( Hu et al.2007). Lake Naivasha is the second largest fresh water lake in Kenya and one of twenty three major lakes of in the Eastern Rift valley, eight in central Ethiopia, a further eight in Kenya and seven in Tanzania (Mireri, 2005). The lake basin supports a vibrant commercial horticulture and floriculture industry, whose growth has accelerated greatly in the past two decades due to the availability of sufficient freshwater for irrigation, good climatic conditions and existing links to local and international markets for vegetables and cut flowers (Legese, 2011). Lake Naivasha was declared a Ramsar site in 1995 and its watershed is mainly a semi-arid environment with scarce surface and underground water Resources (Everard et al.2002, Mireri, 2005).

The Naivasha Lake hydrology and water balance is fed by two main river systems: the Malewa and the Gilgil that enter the lake through a papyrus dominated fringe in the Northern part of the lake. Three smaller river systems that also contribute to the inflow are the Karati, the Nyamithi and the Kwamuya (Everard et al., 2002). The Malewa River contributes approximately $80 \%$, the Gilgil River $10 \%$ and the remainder of the surface inflow flows into the lake through the Karati and other seasonal streams (Abiya, 1996). The Malewa and Gilgil rivers are perennial which may suggest rainfall percolating into groundwater tables in the higher regions. These ground water tables can provide the river with water during dry periods, the base flow. Average stream flow volumes of the Malewa and Gilgil rivers are $153 \mathrm{Mm} 3 /$ year $(4.84 \mathrm{~m} 3 / \mathrm{s})$ and $24 \mathrm{Mm} 3 /$ year $(0.76 \mathrm{~m} 3 / \mathrm{s})$ respectively (Everard et al. 2002). Gaudet and Melack (1981) qualified water that flows into the lake (surface flow) equal to $80 \%$ while $20 \%$ is subsurface flow into and out the lake. The sub surface flow component was calculated as the residual term of the water balance and mayalso contains errors that have not been quantified. Within Naivasha Lake basin, 
three types of ground water flows can be identified. Firstly the subsurface flows towards the lake, Secondly groundwater outflows from the lake towards the deep aquifer and thirdly percolation from the basin directly into the deep aquifer (Meins 2013). From this hypothetical hydrological complex of lake Naivasha, different authors (Everard et al. 2002, Becht and Harper, 2002, Becht et al. 2006, Kuhn et al. 2012, Meins 2013) noted the lake level fluctuation and tried to set up the hydrological model fitting to the lake Naivasha catchment, to more understanding water balance in the lake.

The development of satellite resources such as the Landsat Thematic Mapper (TM/ ETM+) and new techniques for processing and analyzing satellite data offer the potential for augmenting the data collection and resource evaluation efforts of State environmental agencies (Marcus et al. 2001). Surface water is one of the irreplaceable strategic resources for human survival and social development, and it is essential for humans, food crops, and ecosystems (Lu et al. 2011). Remote sensing satellites at different spatial, spectral, and temporal resolutions provide an enormous amount of data that have become primary sources, being extensively used for detecting and extracting surface water and its changes in recent decades (McFeeters, 2013).

The rapid growth of the flower industry, but also population growth (KNBS 2009) and expanding smallholder irrigation has increased the pressure on the volatile water resources (Kuhn et al. 2012) and the fluctuation level in Naivasha lake. These include, a significant dangerous reduction in the size of the Lake Naivasha water body and serious degradation of

water quality (http://www.Vetiver.org/Eth_workshop_09/ethoo\%) caused by: large quantities of sediment inflow from Malewa and Gilgil Rivers, polluting inflows from Naivasha town and intensive flower enterprises adjacent to the lake. These pollutants include high levels of phosphates, nitrates, and pesticide residues, and other agrochemicals leading to gradually the lake eutrophication. 
This study seeks to therefore assess the long time lake Naivasha fluctuation (1986 - 2010) using Land sat images coupled in Remote Sensing and Geographical Information System (GIS) software and Hydrological model considered as the accurate and easier tool for user to monitoring and managing Naivasha Lake catchment.

\section{MATERIALS AND METHODS}

\subsection{Study area}

Lake Naivasha $\left(0^{\circ} 45^{\prime} \mathrm{S} ; 36^{\circ} 26^{\prime} \mathrm{E}\right.$; altitude $\left.1890 \mathrm{~m}\right)$ lies on the floor of Africa's Eastern Rift Valley and, at approximately $160 \mathrm{~km}^{2}$, forms the second-largest freshwater lake in Kenya. It is one of a series of 23 major lakes in the East Rift Valley, eight in central Ethiopia, a further eight in Kenya and seven in Tanzania, spanning latitudes from approximately $7^{\circ} \mathrm{N}$ to $5^{\circ} \mathrm{S}$. Naivasha is suited $80 \mathrm{~km}$ Northwest from Nairobi and the lake basin covers an area of approximately $3400 \mathrm{~km} 2$.

Figure 1: Location of the lake Naivasha 


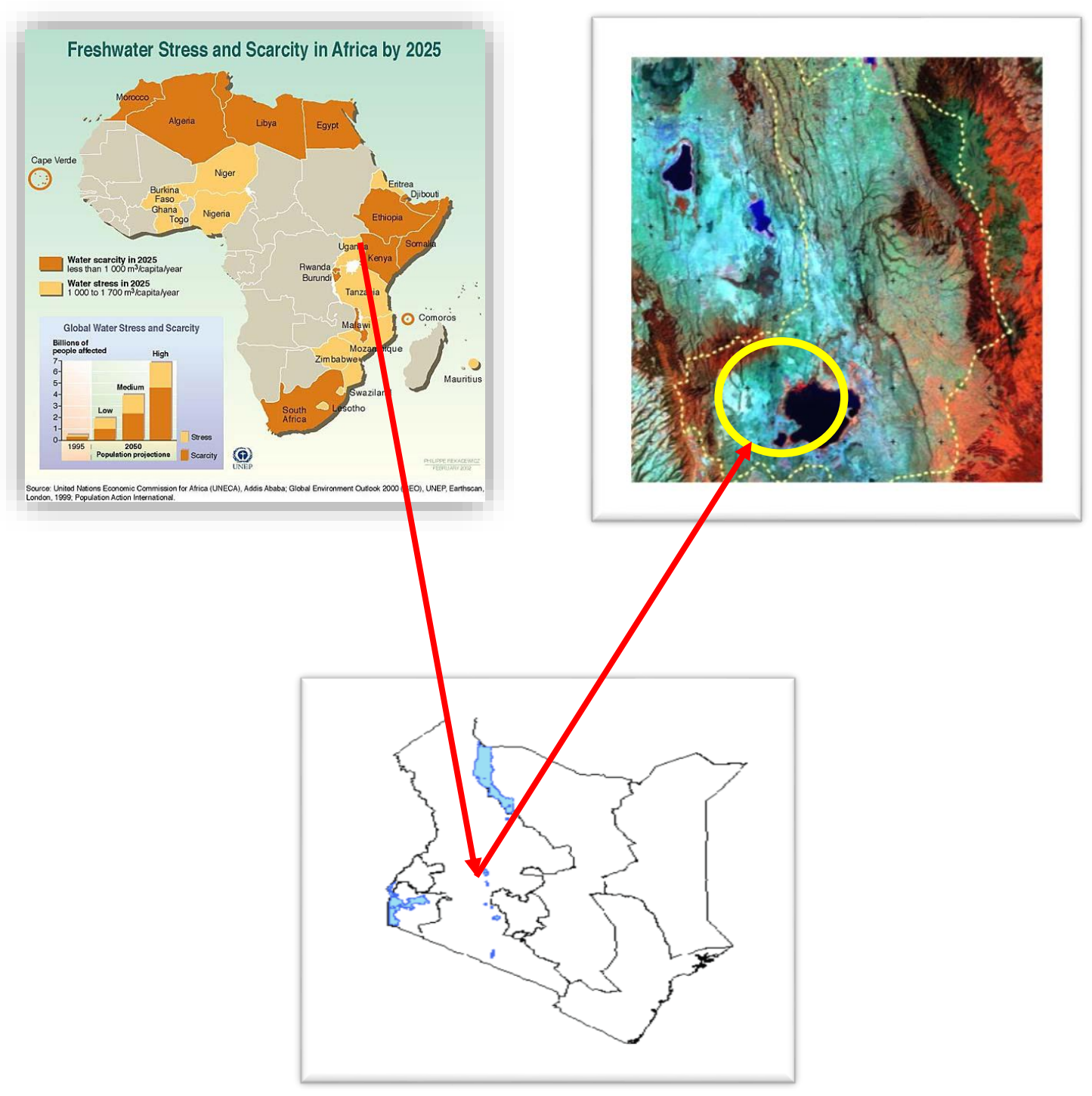

Adopted from: http://www.grida.no/graphicslib/detail/freshwater-stress-and-scarcity-in-africa 


\subsection{Data collection, processing and analysis}

To achieve the aim of this study, the following tasks were performed: Land Sat images collected and processed; creation of an Area of Interest (AOI) and calculation of the Lake area in each image, modeling water balance and lake area fluctuation. Water balance model was set by data input based on the monthly change like inflow from rivers, rainfall on the lake surface, evaporation from the lake surface, and a dynamic groundwater (Becht and Harper, 2002).(Figure

Figure 2. Flow chart of the combined methods ( Land sat image and water balance model) to estimate the Lake Naivasha area changes

Hydrological model

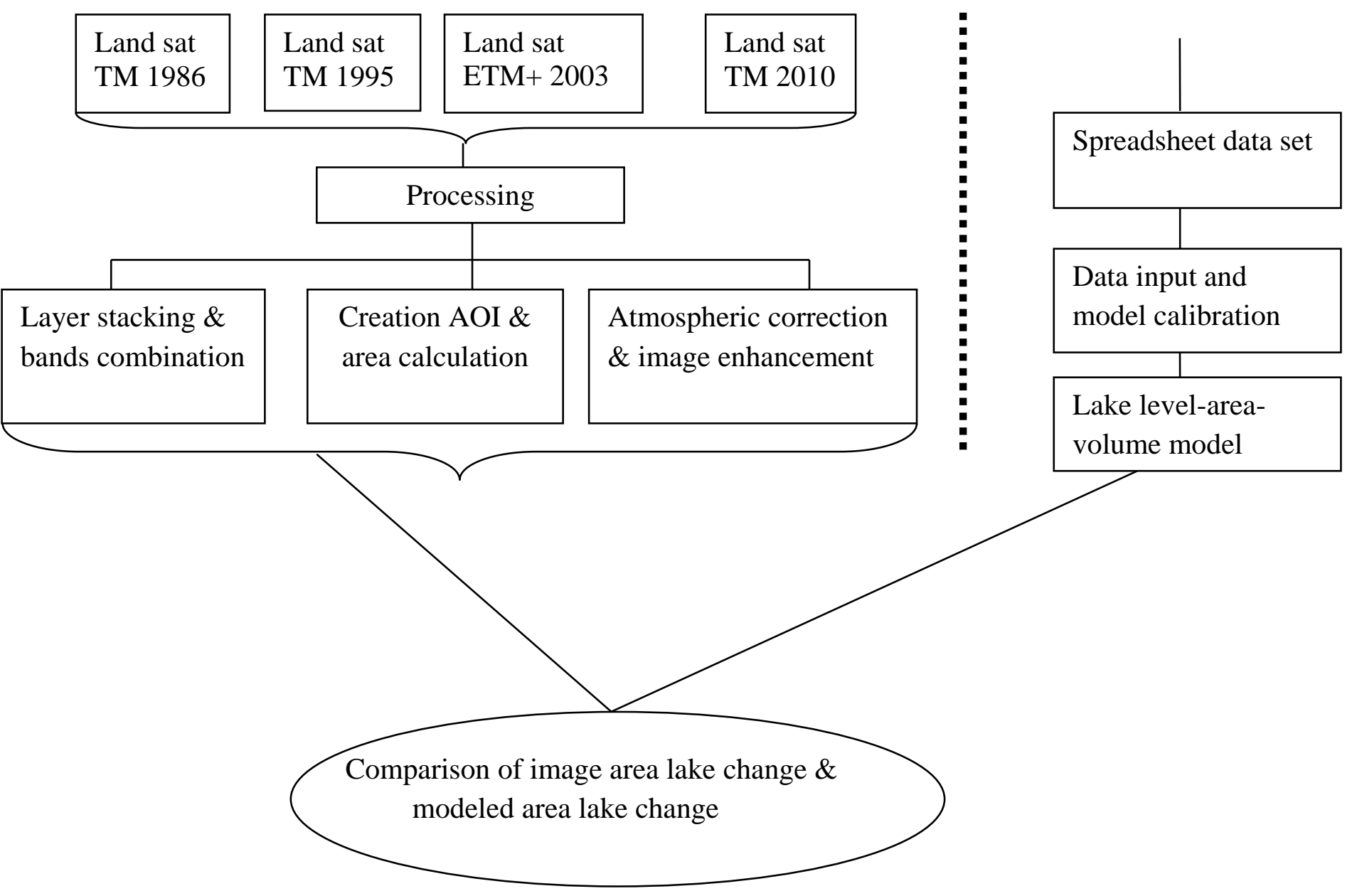


Tree scenes of Land sat 5 TM data acquired in January 1986, January 1995 and January 2010, one scene of land sat 7 ETM+ data acquired January 2003. All the images were obtained from US Geological Survey (USGS) and collected in same month. The obtained Land sat data were pre-geo referenced to UTM 36 using WGS 84 datum. A data set of the spreadsheet/ hydrological model of Lake Naivasha water balance was calibrated by hydro meteorological data Ministry of Environment and Natural Resources (MENR), Government of Kenya (GoK).

Table1 Specification of Land sat image TM/ ETM+

\begin{tabular}{rlllll}
\hline No & $\begin{array}{l}\text { Satellite } \\
\text { Sensor }\end{array}$ & $\begin{array}{l}\text { Spatial } \\
\text { resolution in } \\
\text { meters }\end{array}$ & $\begin{array}{l}\text { Spectral } \\
\text { resolution }\end{array}$ & $\begin{array}{l}\text { Date of } \\
\text { acquisition }\end{array}$ & Source \\
\hline 1 & Landsat TM & 30 & 7 bands & $28 / 01 / 1986$ & $\begin{array}{l}\text { US } \\
\text { Geological } \\
\text { Survey }\end{array}$ \\
& & & 7 bands & $21 / 01 / 1995$ & $\begin{array}{l}\text { US } \\
\text { Geological } \\
\text { Survey } \\
\text { US } \\
\text { Geological } \\
\text { Survey } \\
\text { US } \\
\text { Geological } \\
\text { Survey }\end{array}$ \\
\hline
\end{tabular}

\subsection{Radiometric and geometric correction}

The TM/ETM+ sensors have a spatial resolution of 120-by-120 meters for the thermal-infrared band and 30-by30 meters for the other six spectral bands. The sensors can distinguish 256 levels of brightness (radiance) in each spectral band for each 30-by-30 meters or 120-by-120 meters picture element (pixel). The brightness levels are recorded as digital numbers (DNs) representing the average radiance measured over the ground area corresponding to each pixel. The DN values acquired from different dates should be converted to apparent surface 
reflectance to eliminate radiometric differences and remove solar angle differences. Accurate spatial registration of multi temporal images is essential for change detection (Gong et al. 1992). Misregistration of two images may result in spurious areas of change being detected from images of different dates. It has been suggested that a root mean squared error (RMSE) of 0.5 pixels is the maximum tolerable error for change detection (Gong and Xu 2003, Jensen 2004). However in this study, all image data were acquired by the Land Sat images. Three images were obtained by Landsat5 TM and one was obtained by Landsat $7 \mathrm{ETM}^{+}$and they have almost the same near nadir look angle, and all eight images have the same path and row. The solar angle difference is not removed. We have no information on the atmospheric conditions (water vapour, aerosol) for each date. We only converted digital number values to apparent reflectance by image enhancement. All Land sat images used have already been geometrically corrected by the data distributor.

\subsection{Water balance in Lake Naivasha}

Becht and Harper (2002) used the hydro meteorological data from MENR, GoK dating back to the beginning of $20^{\text {th }}$ Century and developed of a complex spreadsheet model for water balance of the lake and its basin, to understand hydrological scenarios of the lake Naivasha catchment. The model use data of the period from 76 years (1932 -2008). The model is based on the monthly change in a simplified water balance. Components used are inflow from rivers, rainfall on the lake surface, evaporation from the lake surface, and a dynamic groundwater (groundwater inflow/outflow) taking into account the interactions with the aquifer surrounding the lakeThe lake level, area and volume relationship is built into the model and allows the calculation of the rain, evaporation and the dynamic of ground water to simulate the long time fluctuation of the lake level (1932 -2008). The model uses a monthly time step, and is expressed as:

$\triangle \mathbf{S}=\mathbf{R}+\mathbf{I}-\mathbf{E} \pm \mathbf{Q}_{\mathrm{aq}}-\mathbf{Q}_{\text {out }}$

$\triangle \mathrm{S}=$ Lake volume change; $\mathrm{R}=$ rainfall; $\mathrm{I}=$ inflow; E=evaporation; 
$\mathrm{Q}_{\mathrm{aq}}$ is the inflow or outflow from a hypothetical dynamic groundwater aquifer linked to the lake. $\mathrm{Q}_{\mathrm{aq}}=\mathrm{C}\left(\mathrm{H}_{\mathrm{lake}}-\right.$ $\left.\mathrm{H}_{\text {aquifer }}\right) \mathrm{m}^{3}$ month $^{-1}, \mathrm{C}$ is the hydraulic conductance of the aquifer $\left(\mathrm{m}^{2} \mathrm{month}^{-1}\right)$ and $\mathrm{H}$ is the water level (m). The water level in the aquifer is updated using the inflow/outflow calculated for the previous month.

$\mathrm{H}_{\text {aquifer }}=\mathrm{Q}_{\mathrm{aq}} / \mathrm{A} \times \mathrm{S}_{\mathrm{y}}\left(\mathrm{m}^{3} \mathrm{month}^{-1}\right)$ and $\mathrm{H}^{\text {new }}$ aquifer $=\mathrm{H}^{\text {aquifer }}$ old $+\mathrm{H}_{\text {aquifer }}(\mathrm{m})$,

where $A$ is the surface area and $S_{y}$ is the specific yield (porosity) of the aquifer Qout $\left(\mathrm{m}^{3}\right.$ month $\left.^{-1}\right)$ is the water balance deficit, set to a constant for each model run. It lumps to a certain extent balances out all missing parts and errors in the water balance. The major component is the outflow from the lake, but also the long-term unknown inflows from direct runoff and groundwater inflow, the evaporation of riparian vegetation and a systematic over or under estimate of the inflow, rainfall and evaporation area part of this term (Becht et Harper, 2002).

\section{RESULTS AND DISCUSSION}

\subsection{Land sat image}

The bands combination, false color composite (2-3-4) used to detect the change in colors of the lake water body from $t \quad$ Figure 3: Change in area and colors of the Lake Naivasha ;ure3).
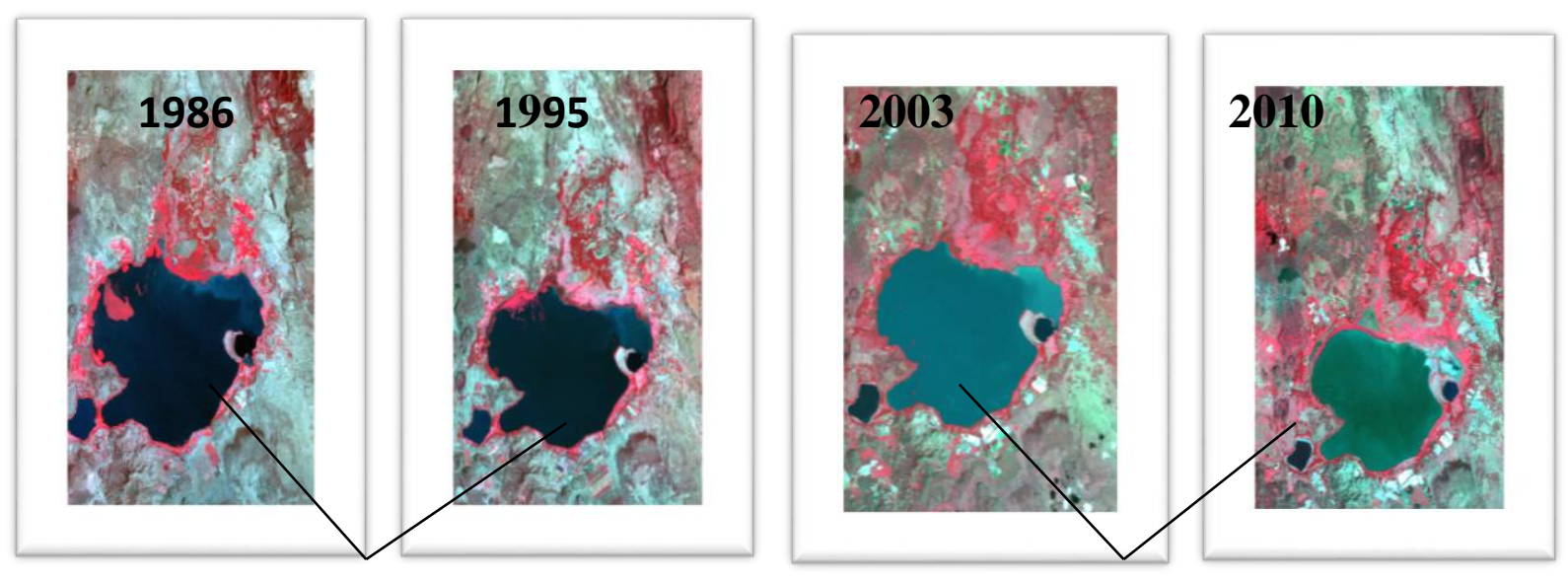

Assumed clear water

Assumed turbid water 
After creation of AOI ( Lake Naivasha catchment), the next step was to extract and calculate of the lake area from different land sat images, 1986, 1995, 2003 and 2010 respectively, using arc map 9.3.1. The output from Erdas and Arc GIS showed a drastic change both in color and surface area of the Lake Naivasha from 1986 to 2010.

Table2: The rate of change in area of the Lake Naivasha

\begin{tabular}{cccc}
\hline Year & Surface Area $\left(\mathbf{K m}^{\mathbf{2}}\right)$ & $\begin{array}{c}\text { Surface Area change } \\
\left(\mathbf{K m}^{\mathbf{2}}\right)\end{array}$ & Change (\%) \\
\hline 1986 & 158.92 & - & - \\
1995 & 143 & 15.92 & 10.01 \\
2003 & 129.47 & 13.53 & 9.46 \\
2010 & 113.2 & 16.27 & 12.56 \\
\hline
\end{tabular}

After calculation the lake areas surface in different years ( 1986, 1995,2003 and 2010 ) respectively. It has been observerd a drastic reduction of thearea to $32.03 \%$ after 24 years . These justified how human activities are more destructive to the lake life more attention to the water hyacinth infestation driven by increasing of nutrient loadings from the horticulture and floriculture industry surrounding the lake Naivasha.

\subsection{Lake Naivasha hydrological modeling}

The output from the model are plotted below (Figure.4, 5 and Figure 6). 


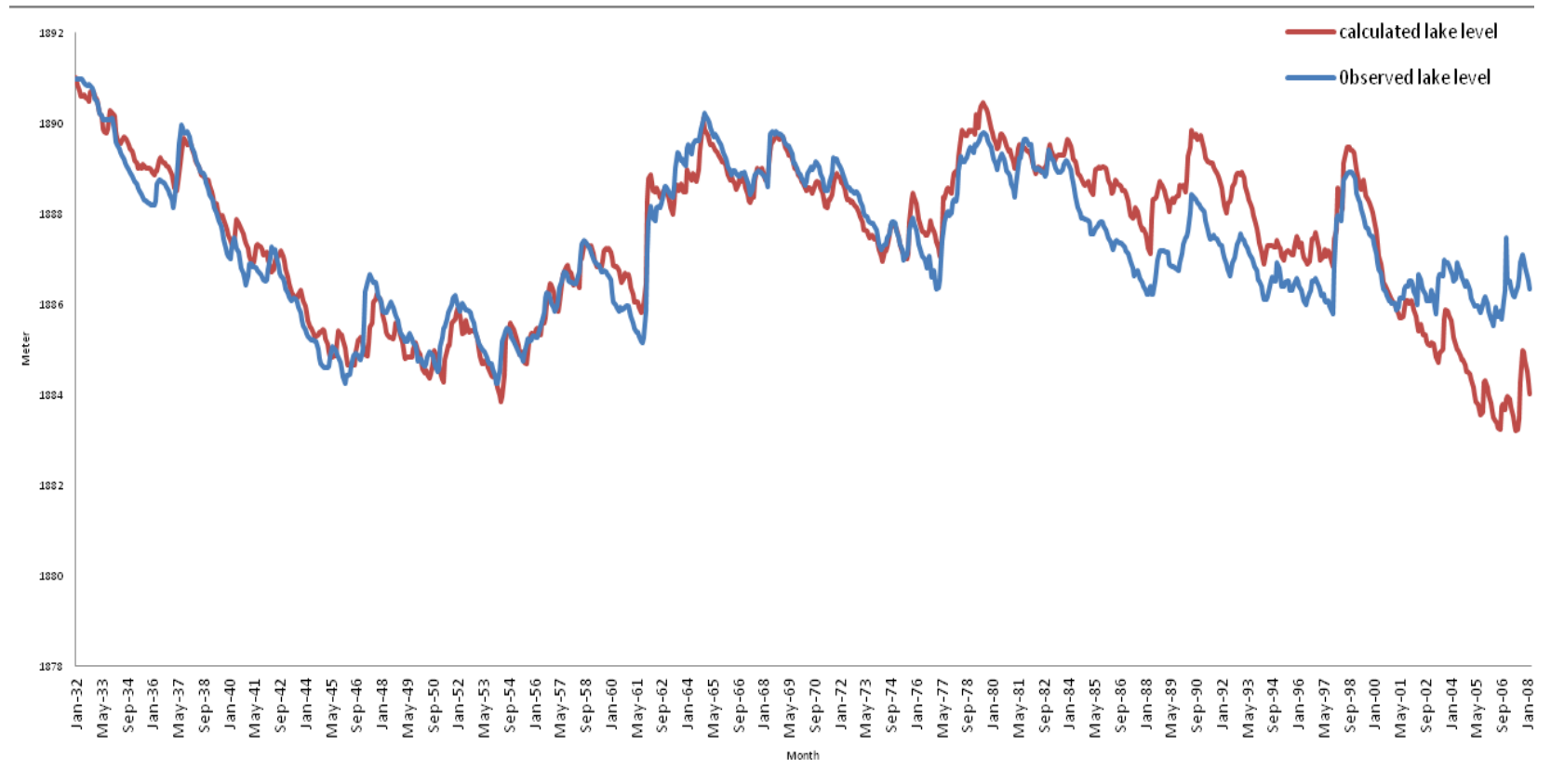

Figure 4: Lake water level fluctuation

The lake water level fluctuation, a set of empirical data to calibrate the model and data input to calculate the lake water level. Both, obseved and calculated showed the correlation results the lake water level fluctuation from 1932 to 2008 . The fluctuation is attributed to rapid increase in demand for lake waters, rivers waters and clearance of the catchment areas for human settlement and associated activities, which lead to the useful of the water from the lake. 


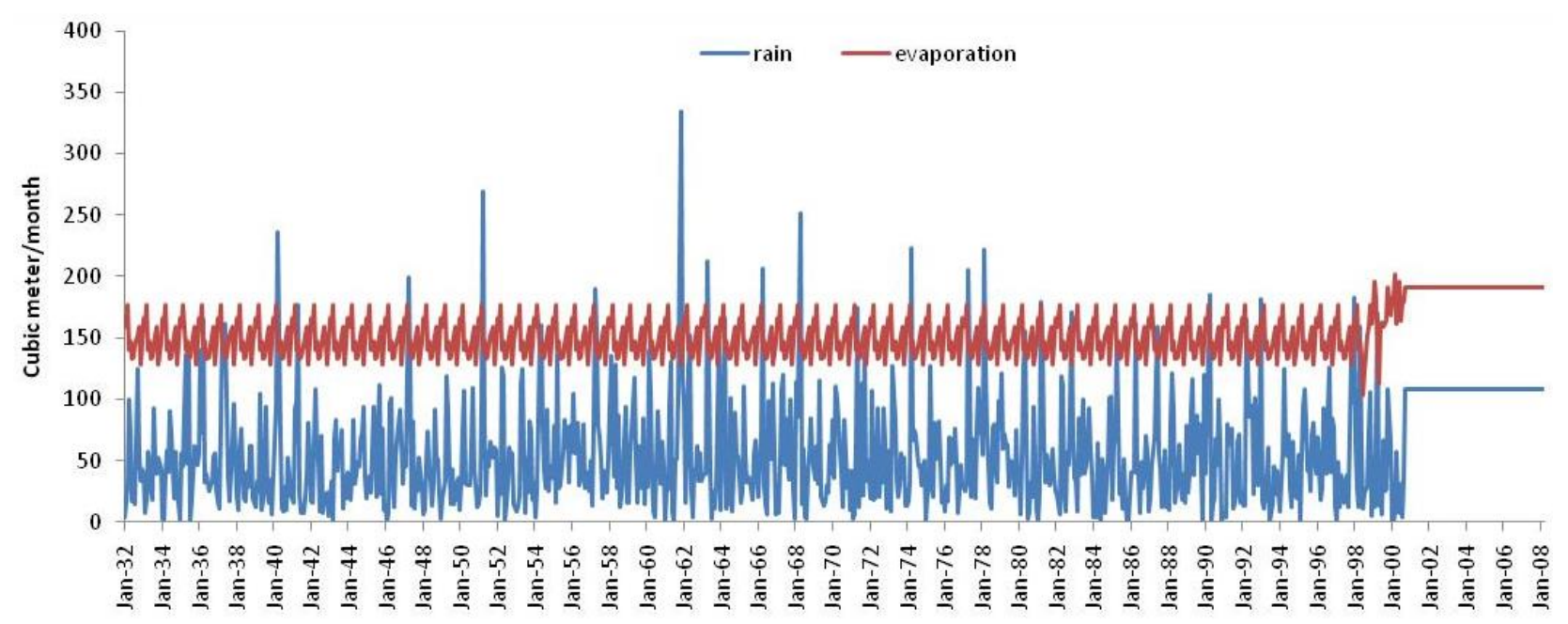

Months

Figure 5: Rainfall/evaporation model of the lake catchment

The rainfall versus evaporation model at the lake area catchment, explain the the water inflow in the lake and outflow from the lake. The water inputs to the lake include rainfall that occurs directly over the lake, inflows from the rivers and surrounding area (runoff) and also through underground water movement from the catchment (seepage-in) Mireri, 2005, Musota 2008. The results aredirectevaporation from the water body and transpiration from the swamp area and other aquatic vegetation (the combined outputs of evaporation and transpiration is referred to as transpiration). According to Mirere 2006, estimated the According to the Naivasha Management Plan (2004), Mireri 2005, the water budget of the Naivasha watershedis water surplus and deficit of $415.8 \mathrm{~m}^{3}$ and $117 . \mathrm{m}^{3}$ million during wet and dry season respectively. 


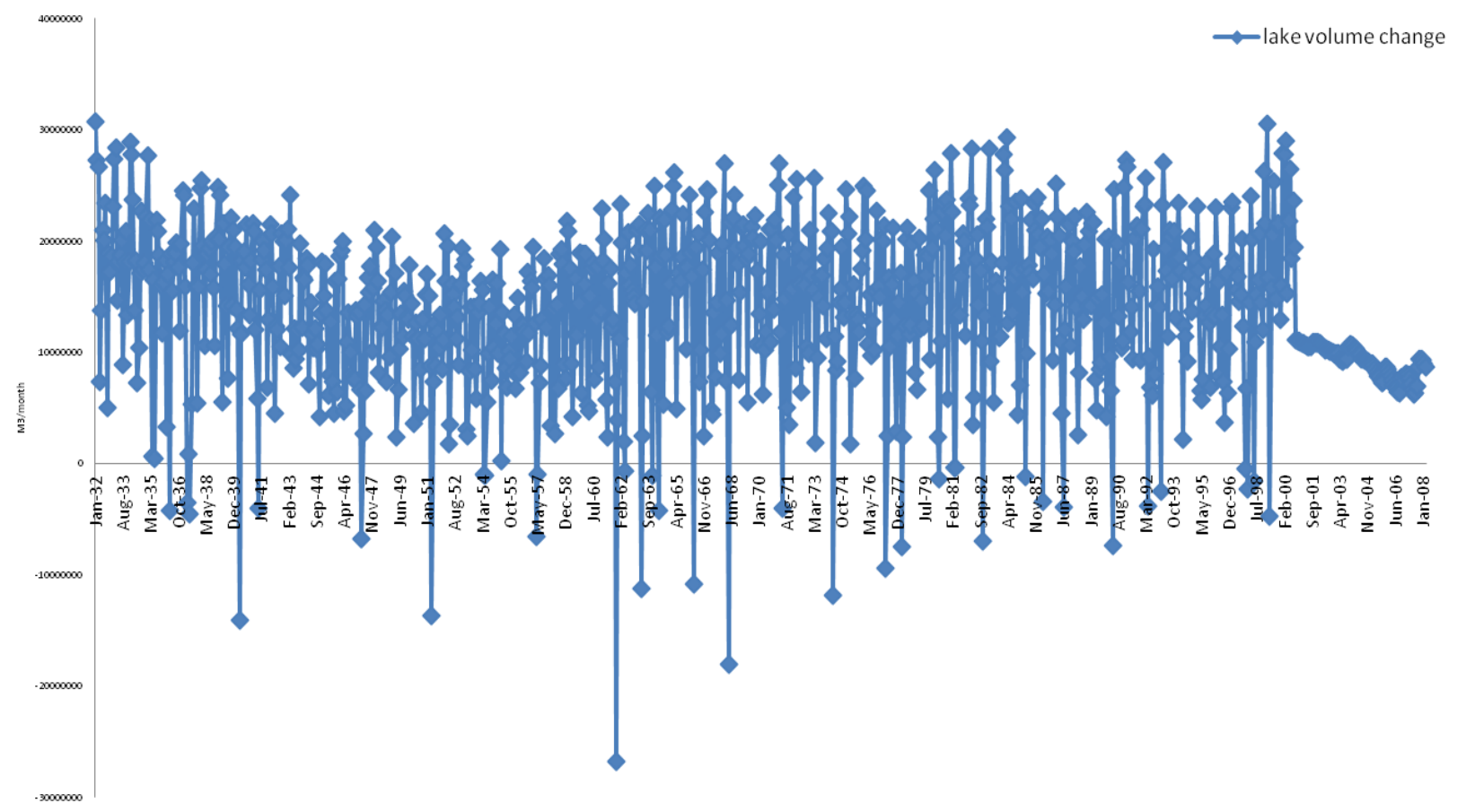

The lake volume fluctuation of the lake is a complex model similated from the inflow or outflow from a hypothetical dynamic groundwater aquifer linked to the lake. The month lake volume fluctuation is related to the volcanic formation of the rift valley lakes,

Becht, et al. (2006), justified the the complex the lake,s volume whereby the last 100 year lake level changed more than twelve meters. Verschuren et al. (2000), studied the lake water level last 1000 years and indentifyingthe four perids where the lake went almost drying. This model explains the fluctuation of the lake volume due to over abstraction of water for irrigation and use in different purposes and high evaporation caused by the overall reft valley semi arid climate.

\subsection{Comparison of the change of surface area Land Sat images and the hydrological model}

To compare the results from the Land Sat images and the hydrological model of 1986, 1995 and 2003 showing the surface area decreasing of Lake Naivasha. The surface area decreased from , $158.92 \mathrm{~km}^{2}$ in 1986 to $143 \mathrm{~km}^{2}$ in 1995 and to $129.47 \mathrm{~km}^{2}$ in 2003 . The hydrological model results showed also that the surface area decreasing from $146 \mathrm{~km}^{2}$ in 1986 to $141 \mathrm{~km}^{2}$ in 1995 
and to $134 \mathrm{~km}^{2}$ in 2003 . The Figure shows Lake surface area change from Land Sat image and Lake Surface area change from hydrological model from 1986 to 2003.

Figure 7: Lake surface area change from Land Sat image and from hydrological model

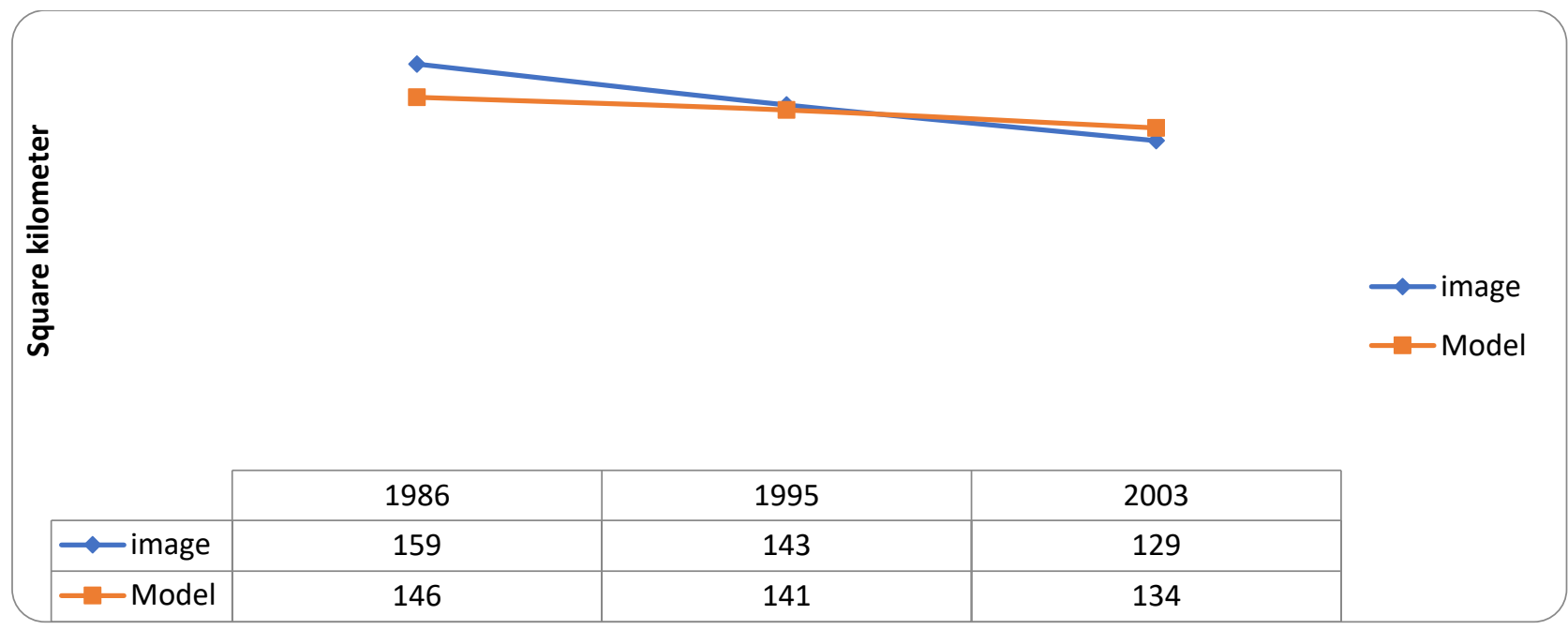

The comparision from the land sat image and hydrological model shows the corration results and prove that, by using earth observation techiniques and empirical hydrological model results almost the same results justifying the area changes of the lake Naivasha from 1986 to 2003.

\section{CONCLUSION}

This study aimed estimate the change of the surface area of Naivasha Lake in the period of 24 years (1986- 2010). Remote sensing, geographical information system and hydrological modeling techniques were used in order to simulate the total surface area change and the main causes which burden Naivasha Lake catchment. The total change of the lake over the time period was estimated in 2010 about $45.72 \mathrm{~km}^{2}$ or $32.03 \%$ while the hydrological model estimated in 2003 about $12 \mathrm{~km}^{2}$ or $8 \%$. The challenges on accessing satellite images cause to use only few years comparing to the data input for the model but the idea of estimating the lake area changes was reached. It is very 
likely that the lake will at risk of losing its entity near the future. The water bodies in Lake Naivasha face serious risks of pollution and nutrient enrichment, because of rapid growth of rural and urbanhuman settlements and intensive/extensive commercial andsmall scale agriculture. Rapid growth of human settlement occurs in the absence of appropriate infrastructure such as water and sanitation. Inadequate planning and development control in the watershed has exposed the area to a serious threat of environmental degradation.

Since the lake is an important source of agricultural production, tourism and electric power, which cluster mainly around the lake. About $70 \%$ of Kenyan flower export (earning about 20 billion Kenyans Shilling in foreign exchange per year) is produced around .Lake Naivasha, while $15 \%$ of Kenyan electric power is generated from the geothermal power generation. All contribute to the Country,s GDP. The following initiatives are recommendable to policy makers and stakeholders for long-term sustainability and management of Lake Naivasha:

- To develop appropriate legal, institutional frameworks and human resources for effective and efficient the lake catchment

- To be based on Pollutant pay system and compensation in Lake Naivasha catchment services to apply payment for environmental services

- To Incorporate the enforcement in Naivasha management plan, including : land use zoning and specifications, and riparian reserve conservation.

- Lake water body and the whole catchment in the meantime monitoring using earth observation techniques with more satellits images and the lake hydrological model will be the important tools for making sustainably long term decision. 


\section{REFERENCE}

Abiya, I. O. (1996). Towards sustainable utilization of Lake Naivasha, Kenya. Lakes and Reservoirs: Research and Management, 2(3-4), 231-242

Becht, R. and.Harper D.M. (2002). Towards an understanding of human impact upon the hydrology of Lake Nivasha, Kenya.http://www.imarisha.le.ac.uk/scientificpublication/agriculture-cultural-hydrology/154.

Becht, R., Odada, E. O., \& Higgins, S. (2006). Lake Naivasha: Experience and lessons learned Initiative.https://www.imarisha.le.ac.uk/scientific publication/policy/155

Ding Y. J., Liu S. Y., Ye B. S. and Zhao L. (2006). “ Climatic implications on variations of lakes in the cold and arid regions of China during the recent 50 years,", Journal of Glaciology and Geo cryology, vol. 28, no. 5, pp. 623-632.

Gaudet, J. J., \& Melack, J. M. (1981). Major ion chemistry in a tropical African lake basin. Freshwater Biology, 11, 309-333.

Gong, P., Ledrew E.F. and Miller, J.R., 1992, Registration noise reduction in difference images for change detection. International Journal of Remote Sensing, 13, pp. 773-779

Gong, P. and Xu, B., (2003). Remote sensing of forests over time: changes types, methods, and opportunities. In Remote Sensing of Forest Environments: Concepts and Case Studies, M. Woulder and S.E. Franklin (Eds), pp. 301-333 (Amsterdam: Kluwer Press)

Hu, Z. G.Wang Y. T, Chi, T. H.. Liu S. H and. Bi. J. T (2007). "Monitoring lake areas based on mixed pixel decomposition combined with double-edge extraction", Remote Sensing Information, no. 3, pp. 34-38.

Jensen, J.R. (Ed.), (2004), Introductory Digital Image Processing: A remote sensing perspective (3rd edn) (Upper Saddle River, NJ: Prentice Hall).

Lake Naivasha, a lake in trouble, a possible solution? Avilable online : http:www.vetiver.org/Eth workshop 09/ethoo\%20 proceedings .htm (accessed on 10 October 2015) 
http://dx.doi.org/10.4314/rj.v1i1S.3D

Lake Naivasha management committee (2004): Lake naivasha management plan. http://web.ncf.ca/es202/naivasha/todays_challenges.html( accessed on 24 October 2016

Legese R. G. (2011). Groundwater and lake water balance of lake Naivasha using 3-D transient groundwater model. University of Twente Faculty of Geo-Information and Earth Observation ITC.thesis. Enschede, The Netherlands. ftp://ftp.itc.nl/pub/naivasha/ITC/LegeseReta2011.pdf

Lu, S.; Wu, B.; Yan, N.; Wang, H. 2011. Water body mapping method with HJ-1A/B satellite imagery.International Journal of Applied Earth Observation and Geoinformation, 13, 428-434.

Marcus C. W., Steeves P. A., Finn J. T. (2001). Use of Thematic Mapper Imagery to Assess Water Quality, Trophic State, and Macrophyte Distributions in Massachusetts Lakes Water-Resources Investigations Report 01-4016.

McFeeters, S.K. (2013). Using the normalized difference water index (NDWI) within a geographic information system to detect swimming pools for mosquito abatement: A practical approach. Remote Sensing, 5, 3544-3561.

Mireri C. (2005). Challenges Facing the Conservation of Lake Naivasha, Kenya. DAAD Summer school , FWU, Vol. 3, (89-98pp) Topics of Integrated Watershed Management Proceedings.

Musota R.. (2008). Using weap and scenrios to assess sustainability of water resources in a basin. case study for Lake Naivasha Catchment-Kenya. Master of Science in Geoinformation Science and Earth Observation, Specialisation: (Water Resources and Environmental Management, Enschede, the Netherlands, 81P.

Verschuren D., Laird K.R., Cumming B.F., (2000). Rainfall and drought in equatorial East Africa during the past 1000 years" Nature 403: 400-414

Water Body Extraction from Multi-Source Satellite Images. Available online:http://citeseerx.ist.psu.edu/viewdoc/download?doi=10.1.1.301.8033\&rep=rep1\&typ e=pdf (accessed on 10 October 2015). 
http://dx.doi.org/10.4314/rj.v1i1S.3D

Rwanda Journal, Series D, Volume 1, 2016, Life and Natural Sciences: Special issue II 